\title{
Digitally Mapping the Hydro-Topographical Context for Community Planning: A Case Study for the Upper Choapa River Watershed in Chile
}

\author{
Gustavo Moran1, Pedro Paolini Cuadra², Valenty Gonzalez³, John-Paul Arp4, Paul A. Arp4 \\ ${ }^{1}$ Surnorte Inc., Aurora, Canada \\ ${ }^{2}$ LP Consultores Ltda., Santiago, Chile \\ ${ }^{3}$ Creativa-Consultores Ltda., Ciudad de Panama, Panama \\ ${ }^{4}$ Faculty of Forestry and Environmental Management, University of New Brunswick, Fredericton, Canada \\ Email: arp2@unb.ca
}

How to cite this paper: Moran, G., Cuadra, P.P., Gonzalez, V., Arp, J.-P. and Arp, P.A. (2017) Digitally Mapping the Hydrogeological Context for Community Planning: A Case Study for the Upper Choapa River Watershed in Chile. Journal of Geoscience and Environment Protection, 5, 265277.

https://doi.org/10.4236/gep.2017.53019

Received: February 22, 2017

Accepted: March 28, 2017

Published: March 31, 2017

Copyright $\odot 2017$ by authors and Scientific Research Publishing Inc. This work is licensed under the Creative Commons Attribution International License (CC BY 4.0).

http://creativecommons.org/licenses/by/4.0/

\section{c) (i) Open Access}

\begin{abstract}
Urban and non-urban settlements in many regions are usually located on the lands bordering shores, rivers, canals or streams. However, housing complexes, landfills, and areas for agriculture and mining are often assigned to locations without sufficiently detailed hydrographic information about subsequent potential if not actual flow and flooding impacts. Yet, for sustainable community planning with emphasis on harmonizing social, economic, environmental and institutional aspects, such information is essential. This article demonstrates how this need can in part be accommodated by way of digital elevation and wet-area modelling and mapping using the upper component of the Choapa watershed in Chile as a case study. The terrain of this area has sharply incised valleys, with communities, fields and roads strung narrowly along the Choapa River and its tributaries. Above these locations along the Estero de Los Pelambres near the Chile-Argentina border are major mining and mineral refining activities. This article provides modelling and mapping details about the wet-to-moist area zonation along the upper Choapa River valleys, and addresses some of the mining-induced changes from 2000 to 2010.
\end{abstract}

\section{Keywords}

Digital Elevation Modelling, Flow-Channel and Wet-Areas Mapping, Communications, Mining, Land-Use, Settlements, Hydrological Concerns

\section{Introduction}

The availability of locally and regionally comprehensive information is critical for discerning the sustainability and extent of hydrological risks to the develop- 
ment of human activities across the residential, industrial, agricultural sectors. Valleys and floodplains are particularly prone to risks of mudslides, erosion and flooding through climate, land-use, topographic and geological circumstances that may act independently or in a combination with each other. This is particularly the case for a country like Chile: small to large cities are located downslope from steep terrain, recurring earthquakes vary in strength from low to catastrophic, and many rivers contain dams for electric power generation and retention of mine-tailings [1].

The purpose of this article is to show how the wet-areas modelling and mapping process (WAM [2] [3]) can be a useful addition to plan and assess the hydrological viability of residential, agricultural and mining developments. This is done by way of a case study focused on the Los Pelambres $\mathrm{Cu}$ mining activities east of Salamanca in the Coquimbo Region of Chile (Figure 1). The information so generated will likely have practical use in planning and communicating about the long-term protection of properties, communities, hydrological infrastructure including supply lines (transport, energy, water) against drought, flooding, and water quality [4].

The wider context for this particular case study is established by a recent social progress study about mining in Chile [5]: while social and economic indicators are suggesting improvements, the rate of progress is still deemed slow in terms of demonstrating comprehensive improvements pertaining to quality of life and

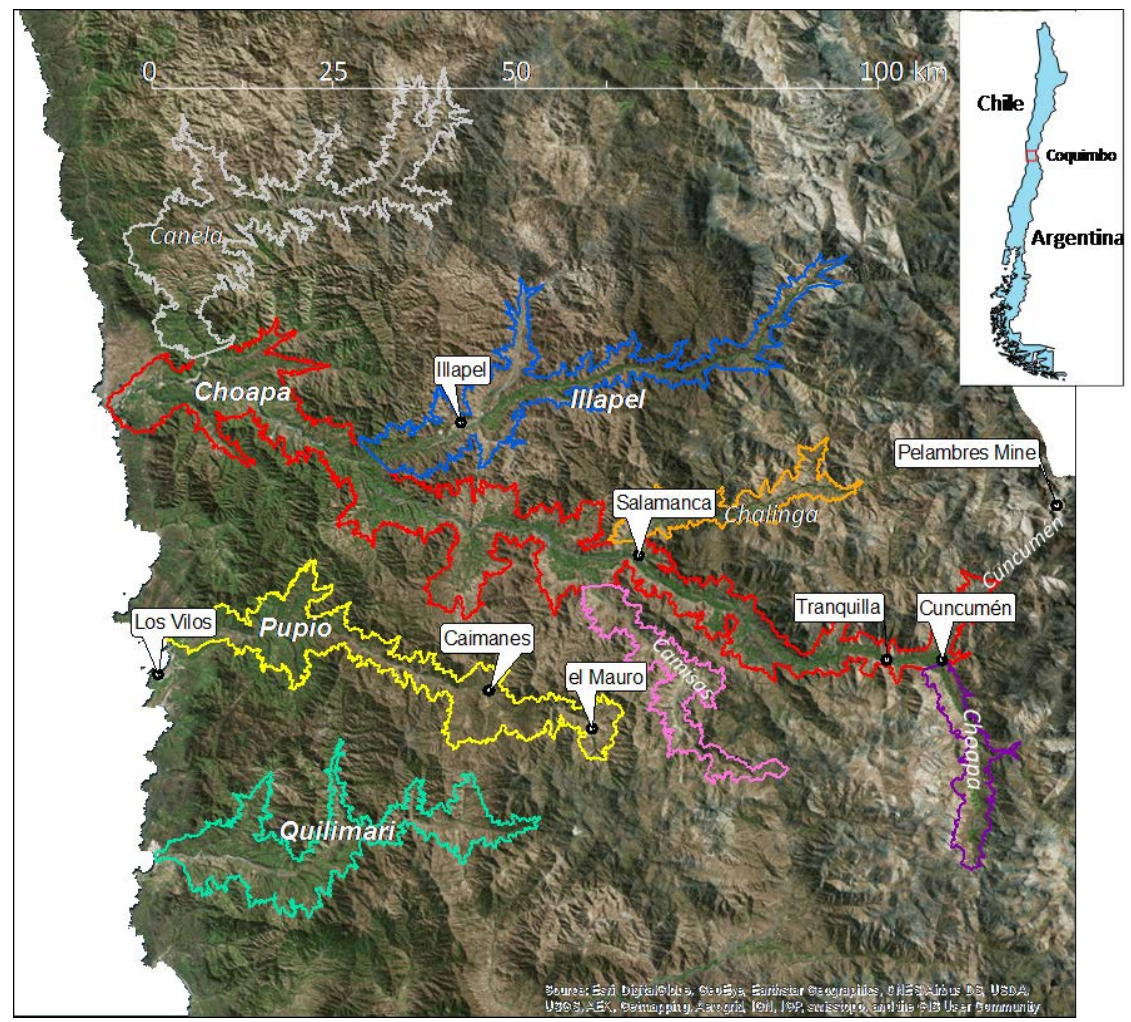

Figure 1. Map focused on the Coquimbo region of Chile, with reference to its major river valleys. Also shown: locations pertaining to mining activities and related community concerns (see text). 
human development. Towards this end, recent communications [6] address many of the difficulties within the Chilean mining sector in reference to whole-projectcycle environmental assessment and management, and to the role for citizen involvement in related decision-making. In addition, innovative Information Communication Technologies [7] [8] have become available to not only facilitate participatory communication, but would also lead to improved project design based on comprehensive project understanding while achieving increased technical to socio-economic project benefits.

\section{Study Area}

The Choapa Province has about 81,000 inhabitants, concentrated in the cities of Salamanca (population 12,000), Illapel (population 22,000) and Los Vilos (population 12,000) [9]. Tension among these inhabitants and elsewhere has increased in recent years due to:

1) Increased competition for water and soil between the residential, land-use and mining sectors; regional GDP contributions: mining 36\%, personal services $13 \%$, construction $10 \%$, tourism $9 \%$, agriculture $5 \%$ [10].

2) A seven-year drought (2007-2014, leading to a water deficit of about $56 \%$ due to a) a temperature increase of $2.7^{\circ} \mathrm{C}$ and $3{ }^{\circ} \mathrm{C}$, and b) a decrease of $20 \%$ to $25 \%$ in annual rainfall [11]. Heavy rain events were reported for Salamanca, Illapel and Los Vilos in 2015 [11].

3) Threat of recurring earthquakes, which reached 8.4 on the Richter scale during 2015 [1].

The article focuses on the upper Choapa River watershed within the Choapa Province of the Coquimbo Region (Figure 2). This watershed $\left(7630 \mathrm{~km}^{2}\right.$ in area and $97 \mathrm{~km}$ long) contains semi-arid climate regions alternating between transitional deserts, steppe, and cold mountains. Elevations range from 0 to $5055 \mathrm{~m}$. The Choapa River has several major tributaries (Canela, Chalinga, Camisas, Illapel, Cuncumén), of which the Cuncumén River watershed contains the mining activities at Los Pelambres (Figure 2). Annual rainfall is low (on average 119 mm per year; Table 1; [12] [13]). At Cuncumén, average monthly flow is essentially even throughout the year at about $2.3 \mathrm{~m}^{3} \cdot \mathrm{sec}^{-1}$, except for October when stream flow more than doubles to $5.7 \mathrm{~m}^{3} \cdot \mathrm{sec}^{-1}$ due to snowmelt (Table 2, [12]). The area above Salamanca towards Los Pelambres supports agricultural, urban and industrial mining activities, with overall land-use coverages amounting to $8.78 \%, 0.65 \%$ and $1.83 \%$, respectively [10].

\section{Methods}

For the hydrological assessment of the Choapa River Watershed, the following resources were used:

1) Shuttle Radar Topography Mission: SRTM digital elevation model (DEM) at 90 and $30 \mathrm{~m}$ resolution (ca. 2000) [14].

2) Advanced Spaceborne Thermal Emission and Reflection Radiometer: ASTER DEM (ca. 2010) [15]. 
3) Both DEMs were interpolated and resampled to $5 \mathrm{~m}$ resolution.

4) Roads and streams (Open Street Map, OSM) [16].

5) Google Earth imagery.

6) Data layers for communities, land-use, and mining activities (Coquimbo regional data layers, Chile), derived from Landsat-8 images [17].

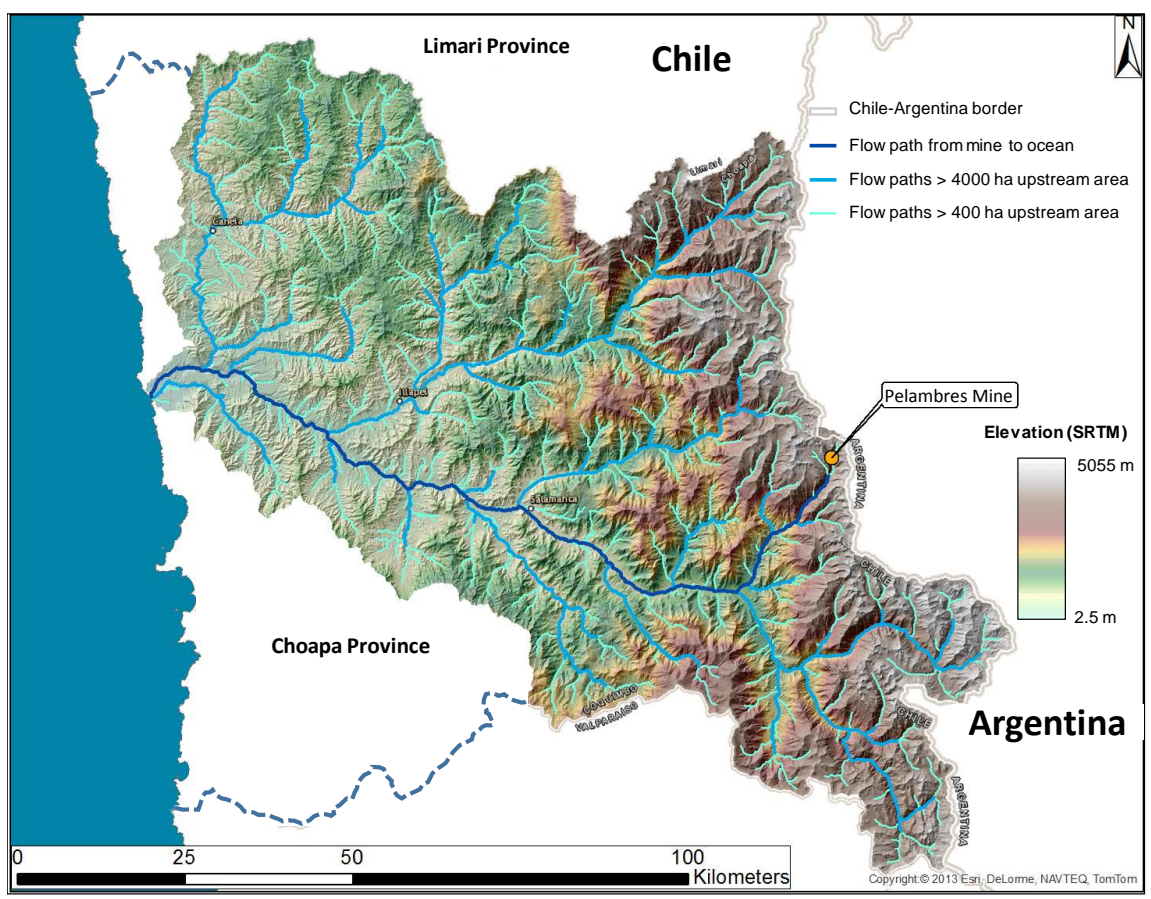

Figure 2. DEM-derived stream and river network of the Choapa River (Figure 1). Drainage pathways were derived from the Global $30 \mathrm{~m}$ SRTM DEM, hydro-conditioned with open street map (OSM) streams. Also shown: location of the open-pit mine at Los Pelambres.

Table 1. Average temperature $\left({ }^{\circ} \mathrm{C}\right)$ and precipitation $(\mathrm{mm})$ for 1960-1990 at La Serena, $193 \mathrm{~km}$ north of Illapel [11] [12].

\begin{tabular}{ccc}
\hline Month & Temperature $^{\circ} \mathrm{C}$ & Precipitation mm \\
\hline January & 17.1 & 0.0 \\
February & 16.9 & 0.0 \\
March & 15.6 & 0.3 \\
April & 13.6 & 1.1 \\
May & 12.3 & 6.7 \\
June & 11.1 & 17.3 \\
July & 10.7 & 35.8 \\
August & 10.9 & 17.5 \\
September & 11.6 & 6.1 \\
October & 12.8 & 1.6 \\
November & 14.0 & 0.3 \\
December & 16.2 & 0.0 \\
\hline
\end{tabular}


Table 2. Average Monthly Flow (2014) for Choapa River at Cuncumén [11].

\begin{tabular}{llllllllllllll}
\hline & \multicolumn{10}{c}{ Average Monthly Flow $\left(\mathrm{m}^{3} \mathrm{sec}^{-1}\right)$} \\
\cline { 2 - 12 } $\begin{array}{c}\text { Choapa } \\
\text { River }\end{array}$ & Jan & Feb & Mar & Apr & May & June & July & Aug & Sept & Oct & Nov & Dec \\
\cline { 2 - 12 } & 3.04 & 2.49 & 2.37 & 2.16 & 2.01 & 2.22 & 2.13 & 2.25 & 2.42 & 5.71 & 2.86 & 2.22 \\
\hline
\end{tabular}

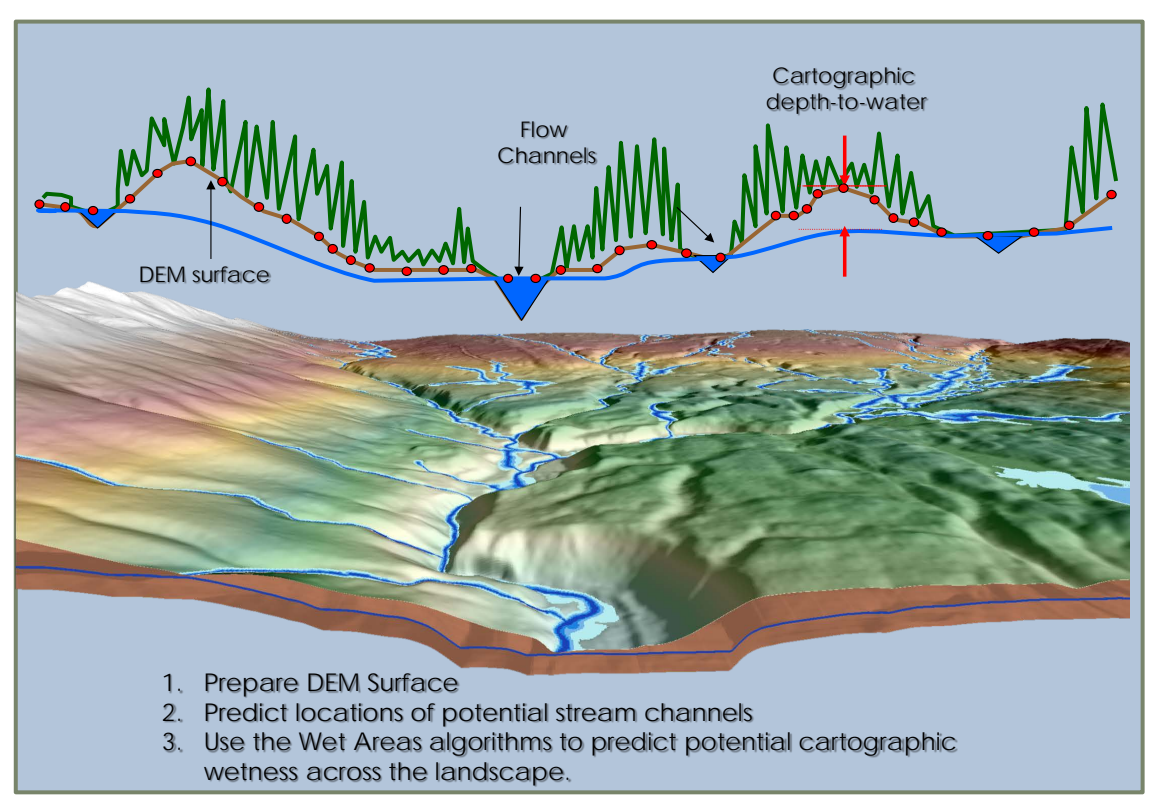

Figure 3. Flow channel and wet-areas mapping concept [2] [3].

7) ArcMap 10.3 [18].

8) Flow-channel and wet-areas mapping process [2] [3].

The flow-channel and wet-areas mapping process (Figure 3) was used to transform the DEMs into hydrologically informative data layers pertaining to land depressions, flow directions, flow accumulations, slope gradients, and the cartographically derived depth-to-water (DTW) indices. The data layers so generated formed the basis for estimating 1) the regional flow networks with seasonal flow and soil wetness variations, 2) the extent of water flow towards and through hydrological infrastructure for specific weather or storm events, 3) the effects of topographic changes where DEMs are available from before specific developments and current conditions, these can be used to determine the development extent of the topographical change (Figures 4-7).

\section{Results}

The flow-channel and wet-areas mapping process (Figure 3) resulted in the maps depicted in Figures 4-7. Figure 4 shows the DEM-based delineation for the wider Los Pelambres mining area in terms of:

1) The sub-catchments outline above the major confluence points of the localflow channel network;

2) The cartographic depth-to-water index up to $40 \mathrm{~m}$ (i.e., DTW $\leq 40 \mathrm{~m}$ ) 


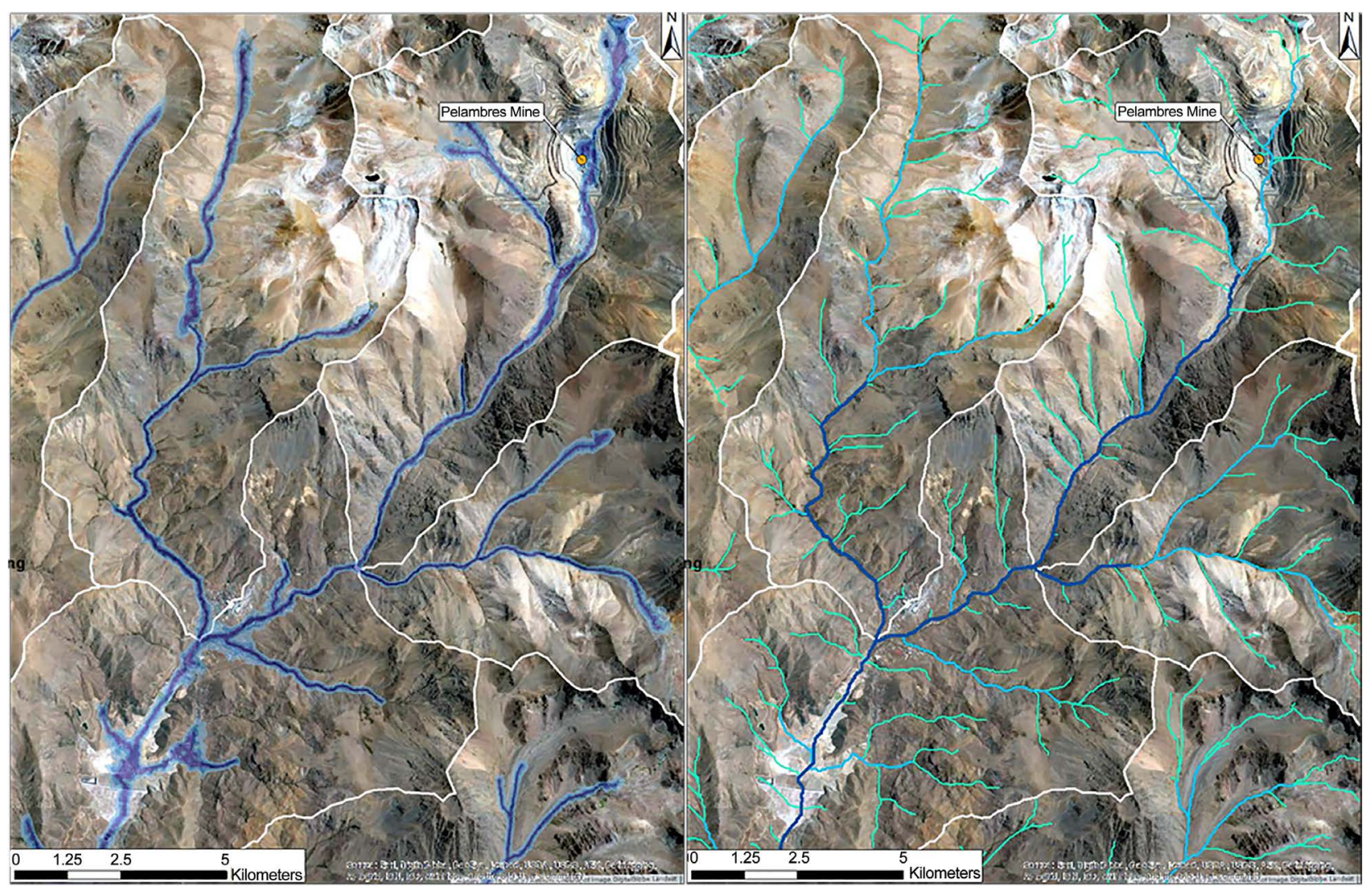

Figure 4. Close-up from Figure 2: Watershed and stream/river delineation detail towards and through the Los Pelambres mineral refinement activities (bottom left) within the upper Choapa River watershed near the Chile-Argentina border. Left: Cartographic depth to water index $(0<\mathrm{DTW}<40 \mathrm{~m}$, shade light to dark blue) for the stream network with $\geq 4000$ ha upslope flow initiation area. Right: Extending the stream network further upslope with $\geq 400$ (shaded lightblue) and $\geq 40$ ha (shaded green) upslope flow initiation areas.

above the local stream network corresponding to an upslope flow initiation area $\geq 4000$ ha;

3) The decrease in stream-network extent from wet to dry seasons or weather conditions as captured by increasing the upslope flow initiation area from 40 to 400 and 4000 ha.

The close-up in Figure 5 pertaining to the Los Pelambres mining locations in Figure 4 outlines some of the DEM-captured elevation changes incurred from 2000 to 2010 using the SRTM and ASTER elevation data, respectively. For the open-pit area these changes refer to increases in mine depth (shaded yellow to red) and subsequent mining-debris fill-in (shaded light to darker green). The corresponding volumes amount to -393 and $+372.4 \mathrm{GL}$, respectively. Figure 5 also provides an outline for 1 ) the Quillayes mine-tailing retention area above the dam, and 2) its dam-stabilization slope (a gradual drop of about $2 \mathrm{~m}$ per 10 $\mathrm{m})$ [1]. The corresponding volumes amount to 144.1 and $63.1 \mathrm{GL}$, respectively. These results were obtained by 1) outlining the borders of the above-and below-dam features from Google Earth imagery (20. Jan, 2015); 2) flattening the SRTM DEM (30 m) across the pond (shaded green); 3) emulating the sloped 

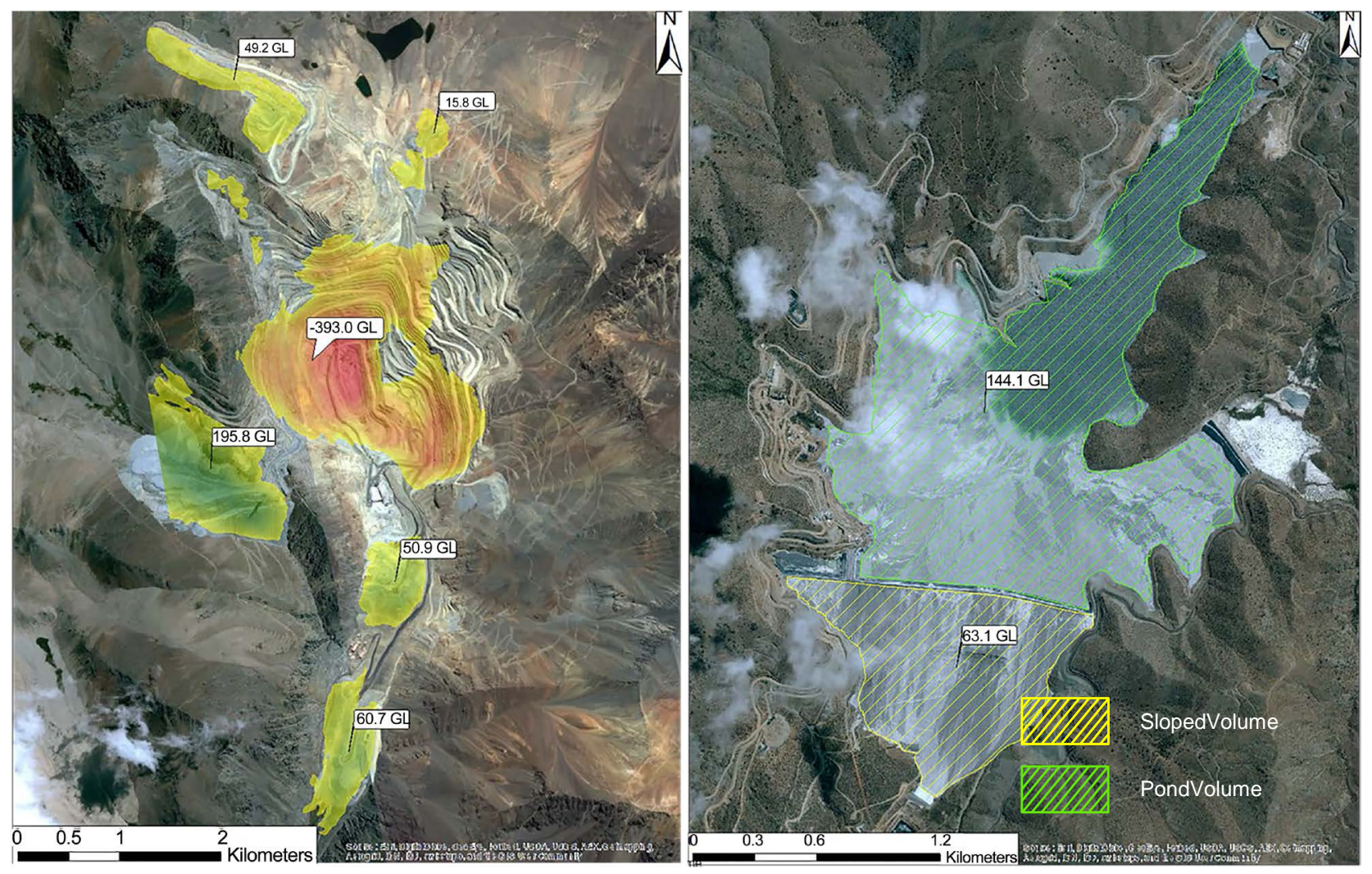

Figure 5. Focusing on the Los Pelambres open-mine and mine tailing pond at Quillayes (decommissioned 2009), overlaid on 2015 Google Earth imagery. Left: Overlaying the pre-development to current elevation differences and related volume changes at the Los Pelambres mine: negative for the pit (shaded yellow to red), positive for the debris layers (shaded light to darkergreen); based on the SRTM DEM (2000) and ASTER (2010)-generated DEMs. Right: Estimating the potential for maximum volume of tailings or drainage water retention and the volume of Earth that was required to sand-fill the slope below the retention dam.

elevations below the retention pond (shaded yellow); 4) determining the pre-topost-elevational changes resulting from dam construction; 5) summing the heights of the $5 \times 5 \mathrm{~m}^{2}$ pixel columns across the area of each feature.

Figure 6 provides an outline of the wider stream network and associated DTW $<40 \mathrm{~m}$ grid for the upper Choapa river system above Salamanca, with area overlays regarding the mining activities (mineral refinement and tailing retention, shaded yellow), land use (shaded green), and villages (shaded red). As it appears, the land used for cultivation is limited to the DTW $<40 \mathrm{~m}$ zone. Based on the satellite imagery for this area (Google Earth), vegetation outside this zone grades from sparse to absent. Residential areas occur within the DTW $<5$ m zone (shaded dark blue), and close to the flow channels. These areas may therefore be subject to potential flooding, flash flooding and mining-debris contamination. Possible contamination threats would be strongest for Cuncumén and Tranquilla below the Quillayes dam, and for Caimanes $49 \mathrm{~km}$ away below the el Mauro dam within the adjacent Pupio watershed to the southwest (Figure 2). The el Mauro dam was completed in 2008 to accommodate the over-capacity production of tailings at Quillayes through pipeline transport (annual tailings transport: 
up to $62.3 \mathrm{Mt}$ [19]). The contamination hazard downslope from these communities would decrease in proportion to the accumulating upslope watershed areas.

Also potentially affected would be the roads along the flow channels, and especially so at the road-stream crossings, for which the upslope watershed areas vary towards Salamanca from 40 to $2200 \mathrm{~km}^{2}$ (Figure 7). These crossings could experience discharge rates amounting to 13.9 and $764 \mathrm{~m}^{3} \mathrm{sec}^{-1}$ following a 30 $\mathrm{mm}$ per day storm or snowmelt event. To visualize the corresponding infrastructure requirements, road-stream crossings with greater than $40 \mathrm{~km}^{2}$ of upslope watershed area would need to be bridged: at $40 \mathrm{~km}^{2}$, culverts would require diameters of at least $2.5 \mathrm{~m}$ to accommodate this flow rate (culvert slope $=0.004$ $\mathrm{m} / \mathrm{m}$; Manning's $\mathrm{n}=0.013$ [20]. While such storm and snowmelt events would be rare [21], they could occur from time to time. Example: flashflood occurrence in northern Chile (Copiapo, Atacama Province) due to a $75 \mathrm{~mm}$ per three days rainfall event in March 2015 over parched upland ground [22].

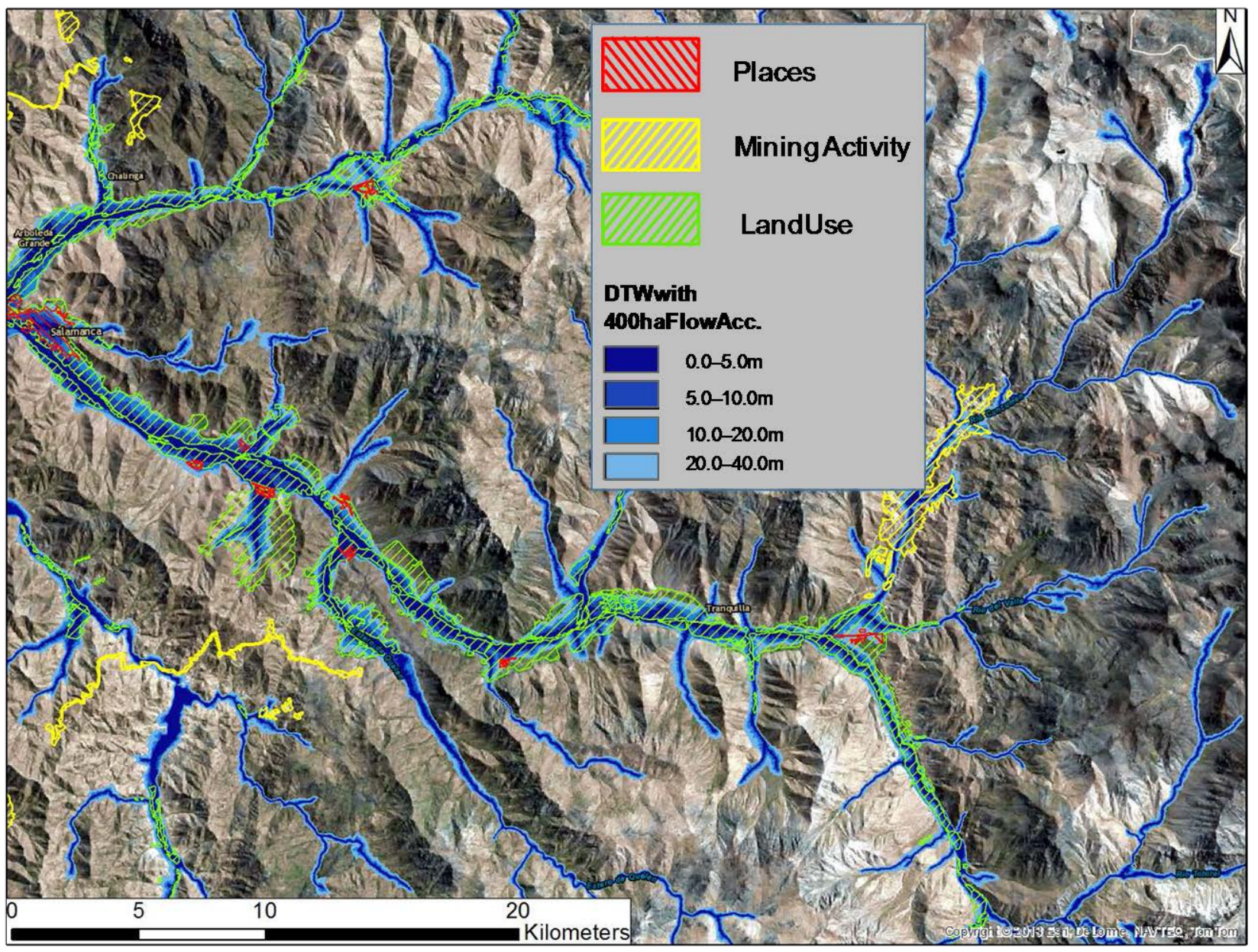

Figure 6. Overlaying the data layers for community locations, land-use pattern and mining activities over the DEM-derived cartographic depth-to-water index (DTW), ranging from 0 to $40 \mathrm{~m}$ (dark to light blue shading, respectively). Note the general conformance between $0<\mathrm{DTW}<40 \mathrm{~m}$ and land-use extent along the major river valleys. Naturally occurring vegetation extends further upslope along streams, but becomes increasingly sparse further up along the slopes and flow channels. 


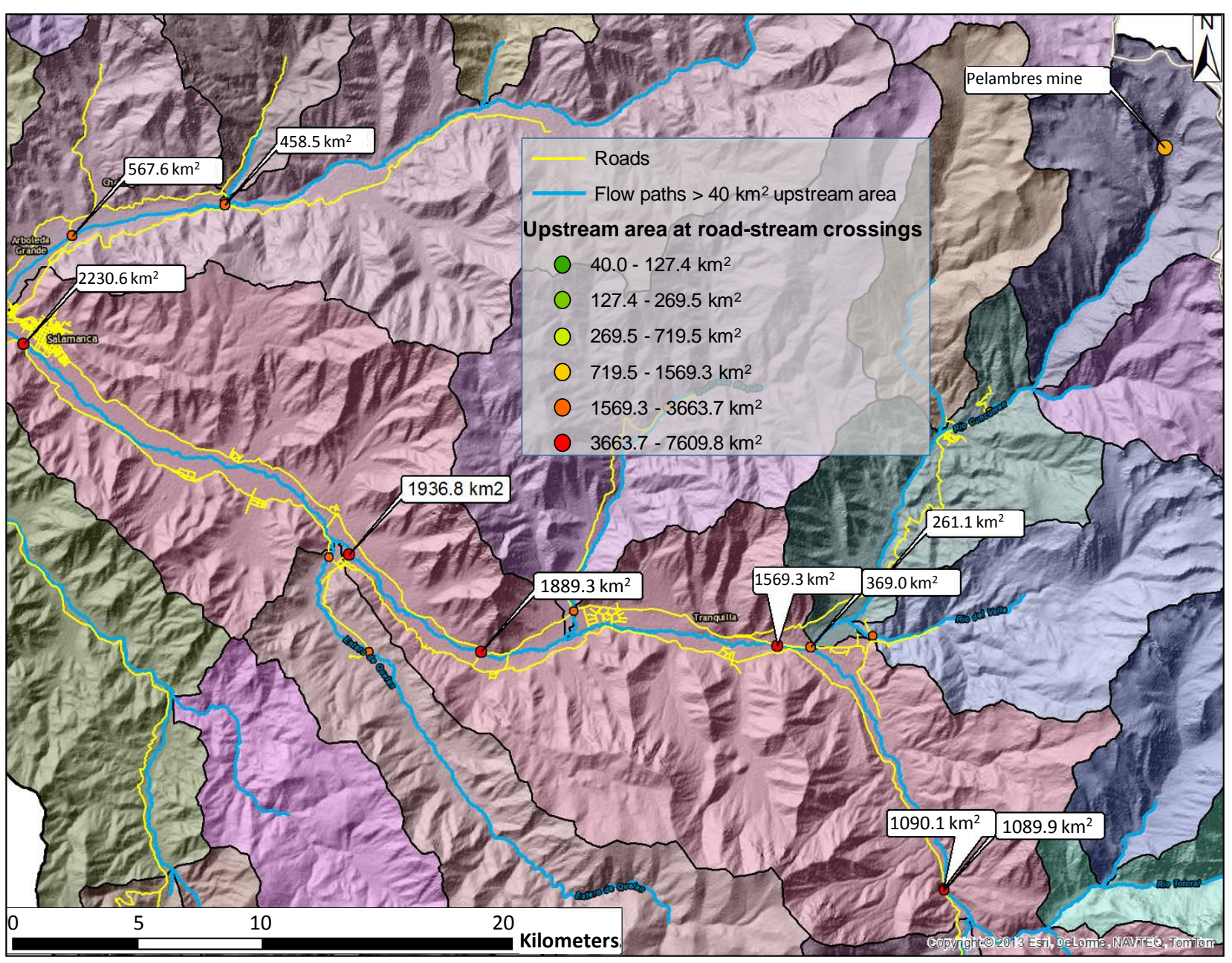

Figure 7. DEM-derived basin network with $>4000$ ha upstream basin areas for the upper component of the Choapa River watershed downslope from the Pelambres mine and east of Salamanca, with upslope watershed areas at each road-stream crossing.

\section{Discussion}

For community planning, the maps in Figures 4-7 and their associated data layers are in principle useful for comprehensively assessing the range of soil moisture regimes, estimating general amounts and availabilities of rain and snowmelt, and determining how these change over time by weather, seasons and across landscapes (see, e.g. [23]). In addition, these maps provide a means 1) to assist in sizing and designing existing or contemplated bridge and culvert installations (Figure 6), and 2) to ensure that residential and industrial developments are not placed within areas prone to flooding, e.g., where DTW $<5 \mathrm{~m}$ below flow-focusing slopes (Figure 7). The extent of flooding can be ascertained by estimating how high floods may rise from the bankful condition (where DTW is set equal to zero) to historical flood stages and beyond as storm events may become more severe. For example, the average October flow rate for Cuncumén at $5.71 \mathrm{~m}^{3} / \mathrm{sec}^{-1}$ (Table 2) requires a culvert diameter of at least $1.6 \mathrm{~m} \mathrm{[20].} \mathrm{This}$ rate translates into a stream discharge rate of $1.63 \mathrm{~mm}$ per day (watershed area $=$ $302.2 \mathrm{~km}^{2}$ ). A rainfall anomaly of, e.g., $30 \mathrm{~mm} /$ day, however, would increase the 
stream discharge rate to $105.1 \mathrm{~m}^{3} \mathrm{sec}^{-1}$ at this location.

For the mining purpose, the maps in Figure 5 and Figure 6 and their associated data layers could be used:

1) to estimate 1) the amounts and flow rates of incoming water to avoid flooding along hydrologically critical points, such as overall flow input into and out of the mined areas and retention ponds, and 2) the capacity of ponds to receive additional water and sediments (Figure 5);

2) to minimize flow channel influence and soil wetness by placing industrial and residential infrastructure components away from flow and wetness compromised areas;

3) to restrict off-road traffic along slopes and wet areas to minimize soil damage and erosion;

4) to protect communities and habitats against inadvertent spills by capturing or steering potential spill trajectories away from these locations through spillway design.

As mining operations open, close, and further evolve, much needs to be done in terms of stabilizing mining sites and associated tailing retention by reclamation. It is suggested that the approach illustrated with Figures 4-7 could enable comprehensive reclamation planning by delineating likely flow paths, wet areas and potential flooding zones within small to large watersheds. Currently, many abandoned mining locations have as yet no plans or treatments for accumulated contaminants in ponds and soils [24]. This would include addressing some of the many issues arising at, e.g., Los Pelambres and at the el Mauro tailing dam, located about $9 \mathrm{~km}$ above Caimanes (Figure 2, Figure 4; [1] [4]). Such planning could also include finding and optimizing locations and design for dry (dewatered) tailing stacks [25].

For land-use planning purposes, the maps in Figures 4-7 form the basis for high-resolution soil drainage mapping [2]. In this, the DTW component in Figure 7 can be used for optimizing crop productivities in agriculture and forestry by accounting for local in-field soil wetness and dryness variations, with emphasis on selecting areas that are, e.g., best for wet-area farming practices, wetland and wildlife conservation, and/or stormwater management.

\section{Concluding Remarks}

The increasing availability of digital elevation models and related geospatial interpretations open up many new avenues aimed at comprehensively assessing changes in hydrological conditions across landscapes and jurisdictions, including past, current, and future mining and land-use projects. As illustrated, this can be done from local to regional scales and across time using multi-temporal DEMs and surface images. For technical purposes, and as demonstrated elsewhere [26], it is best to increase the spatial resolution of the bare-Earth DEMs and images to at least $1 \mathrm{~m}$, especially for the design element of placing hydrological infrastructure. The advantages of doing so refer to 1) a better delineation of all local flow patterns, depressions, and structures, and 2) a more reliable inter- 
pretation of soil wetness, extent of flooding and flood plains, including terraces. For the mining sector, all of this could become part of whole-project cycle design, assessment, and best management practices.

As accurate DTW-based wet-areas mapping enters the jurisdictional and public domain through knowledge exchange, education and real estate evaluations, it will become known how each parcel of land and property is hydrologically situated within its general neighborhood. Downslope locations are particularly vulnerable as they would be affected by soil wetness, upslope water retention or diversion, soil erosion, gully formation, slope destabilization, mudslides, and flooding. Anticipating this through systematic wet-areas mapping should therefore lead to better technical, financial and socio-economic decision-making. In addition, contending parties (e.g., mining companies, concerned citizens) can both discuss and appraise if not support suggested land and water-based plans and operations. In all of this, information as presented in Figure 6 and Figure 7 and the underlying data layers are basic to discern 1) how specific weather events would affect communities, mining facilities and transportation structures, and especially in frequent earthquake zones, and 2) what can be done to reduce the potential risks so arising.

From a technical perspective, producing reliable wet-areas maps requires specialized expertise and algorithms to compile, configure, read, process and store terabytes of information in relatively short time as the demands for wet-areas maps and related data layers increase overtime. In this, great care goes into the development of highly efficient software and tools to manage and process the data for seamless high-resolution mapping at property to regional scales [27]. For general and specific communications purposes, the maps and data layers so produced conform to user-friendly GIS formats (e.g., .pdf, .kmz).

\section{Acknowledgements}

This work was supported through the Forest Watershed Research Centre activities at the Faculty of Forestry and Env. Management at UNB, Fredericton, New Brunswick, Canada.

\section{References}

[1] Valenzuela, L. (2016) Design, Construction, Operation and the Effect of Fines Content and Permeability on the Seismic Performance of Tailings sand Dams in Chile. Obras y Proyectos, No. 19, 6-22. https://doi.org/10.4067/S0718-28132016000100001

[2] Murphy, P.N.C., Ogilvie, J., Meng, F.R., White, B., Bhatti, J.S. and Arp, P.A. (2011) Modelling, and Mapping Topographic Variations in Forest Soils at High Resolution: A Case Study. Ecological Modelling, 222, 2314-2332.

[3] White, B., Ogilvie, J., Campbell, D.M.H., Hiltz, D., Gauthier, B., Chisholm, H.K., Wen, H.K., Murphy, P.N.C. and Arp, P.A. (2012) Using the Cartographic Depth-toWater Index to Locate Small Streams and Associated Wet Areas across Landscapes. Canadian Water Resources Journal, 37, 333-347.

https://doi.org/10.4296/cwri2011-909

[4] Lehne, F. (2014) Caimanes and the Water-Infinite Legal Struggles about a Finite 
Good. Future of Food: Journal on Food, Agriculture and Society, 3, 94-100.

[5] Parra, C. and Franks, D. (2011) Monitoring Social Progress in Mining Zones-The Case of Antofagasta and Tarapaca, Chile. 1st International Seminar Responsibility in Mining, Santiago, 19-21 October 2011.

[6] Public Coordination System and Permanent Dialogue (2016) XIV International Congress (Valor Minero).

https://www.csiro.au/en/Research/Mining-manufacturing/CSIRO-Chile/Future-ofMining

[7] Information Communications Technologies (ICT). https://en.wikipedia.org/wiki/Information_and_communications_technology

[8] Banco Interamericano de Desarrollo (BID) (2014) Guía metodológica: Iniciativa ciudades emergentes y sostenibles. http://www.gobiernolocal.gob.ar/?q=node/4330

[9] Instituto Nacional de Estadisticas. Chile. http://www.ine.cl/canales/chile_estadistico/familias/demograficas_vitales.php

[10] Banco Central de Chile (2013) PIB por Región (Regional GDP).

[11] Dirección General de Aguas (DGA), Chile. http://www.dga.cl/servicioshidrometeorologicos/Paginas/default.aspx

[12] Andersen, L.E. and Verner, D. (2010) Social Impacts on Climate Change in Chile. Policy Research Working Group 5170, 29 p.

[13] Montecinos, S., Gutierrez, J.R., Lopez-Cortes, F. and Lopez, D. (2016) Climatic Characteristics of the Semi-Arid Coquimbo Region in Chile. Journal of Arid Environments, 126, 7-11.

[14] Shuttle Radar Topography Mission: SRTM Digital Elevation Model (DEM) at 90 and 30 mresolution (ca. 2000). http://www2.jpl.nasa.gov/srtm/

[15] ASTER DEM (ca. 2010). https://asterweb.jpl.nasa.gov/

[16] Open Street Map, OSM. https://www.openstreetmap.org/\#map=11/-31.7833/-71.0167

[17] Topaloğlu, R.H., Sertel, E. and Musaoğlu, N. (2016) Assessment of Classification Accuracies of Sentinel-2 and Landsat-8 Data for Land Cover/Use Mapping. International Archives of the Photogrammetry, Remote Sensing and Spatial Information Sciences, XLI-B8, X1055-1059.

[18] ESRI. ArcMap. https://desktop.arcgis.com/en/arcmap/

[19] AUSENCO (2013) Los Pelambres Mauro/Quillayes Dam. http://www.ausenco.com/case-studies/los-pelambres\#

[20] Vlab (2016) 16XXX: Online Calculations. http://onlinecalc.sdsu.edu/onlinechannel03.php

[21] Suárez, F., Muñoz, J.F., Fernández, B., Dorsaz, J.-M., Hunter, C.K., Karavitis, C.A. and Gironás, J. (2014) Integrated Water Resource Management and Energy Requirements for Water Supply in the Copiapó River Basin, Chile. Water, 6, 2590 2613. https://doi.org/10.3390/w6092590

[22] International Federation of Red Cross and Red Crescent Societies (2015) Chile: Flash Floods. DREF Emergency Plan of Action (EPoA), 22 p. http://reliefweb.int/sites/reliefweb.int/files/resources/MDRCL011do1.pdf

[23] Jones, M.-F., Castonguay, M., Nasr, M., Ogilvie, J., Bhatti, J. and Arp, P.A. (2014) Modeling Hydrothermal Regimes and Potential Impacts of Climate Change Permafrost within the South Mackenzie Pain, Northwest Territories, Canada. Écoscience, 21, 21-33. https://doi.org/10.2980/21-1-3663

[24] Weeks, B. (2015) Mine Closure in Chile-Challenges and Changes. Geotechnical 
News, March 2015, 43-45.

[25] Pimenta de Ávila, J. (2011) Thedrained Stacking of Granular Tailings: A Disposal Method for a Low Degree of Saturation of the Tailings Mass. Proceedings of Tailings and Mine Waste, Vancouver, 6-9 November 2011.

[26] Arp, P.A. (2015) How Much Water: When? Where? Pan European Networks, Issue 14 (Materials Wealth), 212-213.

http://www.paneuropeannetworkspublications.com/ST14/\#212

[27] Ogilvie, J. (2014) A Technical Overview of Alberta's Wet-Areas Mapping Datasets. http://watershed.for.unb.ca/a-technical-overview-of-albertas-wet-areas-mapping-da $\underline{\text { tasets/ }}$

Submit or recommend next manuscript to SCIRP and we will provide best service for you:

Accepting pre-submission inquiries through Email, Facebook, LinkedIn, Twitter, etc. A wide selection of journals (inclusive of 9 subjects, more than 200 journals)

Providing 24-hour high-quality service

User-friendly online submission system

Fair and swift peer-review system

Efficient typesetting and proofreading procedure

Display of the result of downloads and visits, as well as the number of cited articles Maximum dissemination of your research work

Submit your manuscript at: http://papersubmission.scirp.org/

Or contact gep@scirp.org 